\title{
Efektivitas integrasi asesmen formatif concept checks pada pembelajaran fisika dalam meningkatkan kemampuan kognitif siswa SMA
}

\author{
Hani Nur Azizah \\ Program Studi Pendidikan Fisika, Universitas Pendidikan Indonesia, Indonesia \\ Surat-e: haninurazizah@student.upi.edu

\section{Ridwan Efendi} \\ Departemen Pendidikan Fisika, Universitas Pendidikan Indonesia, Indonesia \\ Surat-e: ridwanefendi@upi.edu

\section{Saeful Karim} \\ Departemen Pendidikan Fisika, Universitas Pendidikan Indonesia, Indonesia \\ Surat-e: saefulkarimsk@gmail.com
}

\begin{abstract}
Abstrak. Penelitian ini dilatarbelakangi oleh hasil studi pendahuluan yang menunjukkan bahwa masih banyaknya pendidik yang menerapkan penilaian hanya untuk mengetahui hasil belajar siswa di akhir pembelajaran. Oleh karena itu, diperlukan suatu penilaian yang dapat meningkatkan pemahaman siswa selama pembelajaran yang dikenal dengan asesmen formatif. Tujuan dari penelitian ini adalah untuk menunjukkan efektivitas asesmen formatif concept checks dalam meningkatkan kemampuan kognitif siswa SMA. Metode penelitian yang digunakan adalah quasi experimental design dengan desain penelitian Nonequivalent Control Group Design. Sampel pada penelitian ini terdiri dari 59 siswa kelas X di salah satu SMA Negeri di kota Bandung. Pengumpulan data dilakukan melalui tes kemampuan kognitif yang dianalisis menggunakan uji $\mathrm{t}$ dan effect size. Hasil penelitian menunjukan bahwa terdapat perbedaan peningkatan kemampuan kognitif siswa antara kelas eksperimen dengan kelas kontrol dan nilai effect size yang termasuk dalam kategori sedang. Secara keseluruhan Integrasi asesmen formatif concept checks pada pembelajaran fisika efektif terhadap peningkatan kemampuan kognitif siswa..
\end{abstract}

Kata kunci: Asesmen Formatif, Concept Checks, Kemampuan Kognitif

\begin{abstract}
This research is motivated by the result of a preliminary study, which shows that there are many educators who apply assessment only to find out the student learning outcomes at the end of learning. Therefore, an assessment is needed that can improve students' understanding during learning, known as a formative assessment. The purpose of this study is to know the effectiveness of formative concept checks on students' cognitive abilities. The research method was used a quasi-experimental design with one group pretest-posttest design. The sample in this study was class X students senior high school in Bandung, an amount of 59 students. The data collection was conducted through a cognitive abilities test. The data were analyzed using the t-test and effect size. The results showed that there was a difference in the increased cognitive ability of students between the experimental class and the control class and the effect size value included in the medium category. This shows that the integration of formative assessment concept checks in physics learning was effective in improving the cognitive abilities of students.
\end{abstract}

Keywords: Formative Assessment, Concept Checks, Cognitive Abilities 


\section{Pendahuluan}

Penilaian adalah proses pengumpulan informasi tentang capaian pembelajaran siswa yang dilakukan secara terencana dan sistematis dengan tujuan untuk memantau dan mengevaluasi proses, kemajuan belajar, dan perbaikan hasil belajar siswa secara berkesinambungan [1]. Penilaian dalam pembelajaran baik kualitatif maupun kuantitatif adalah satu hal yang memungkinkan dalam mengidentifikasi tidak hanya konsep dan isi yang dicapai siswa tetapi juga alasan kegagalan siswa dalam memahami konsep [2]. dilakukan, sampai dimana pemahaman saat ini, apa masalah yang masih ada, apa hipotesis Anda, dan apa yang akan Anda lakukan.

Masalah mendasar dari praktik penilaian adalah tidak terintegrasinya penilaian yang dapat mengembangkan pemahaman konseptual siswa [3]. Penilaian yang umum dilakukan oleh guru-guru di sekolah hanya berupa uji kompetensi tertulis di akhir seluruh konsep pembelajaran atau yang biasa disebut sebagai asesmen sumatif. Fakta di lapangan menunjukkan masih terbatasnya guru di berbagai jenjang pendidikan yang melakukan penilaian formatif selama proses belajar, karena penilaian yang sering dilakukan yaitu menilai hasil belajar siswa (penilaian sumatif) [4] .

Penilaian yang sering dilakukan guru-guru di sekolah adalah dengan memberikan pekerjaan rumah dan meminta siswa untuk mengumpulkannya pada pertemuan berikutnya tanpa adanya umpan balik yang diberikan dari guru kepada siswa [5]. Hal tersebut diperkuat dengan studi awal yang dilakukan berupa wawancara kepada beberapa guru di sekolah penelitian. Data yang diperoleh dari hasil wawancara tersebut adalah sebanyak $40 \%$ guru melakukan penilaian saat pembelajaran dalam bentuk kuis ataupun tugas sedangkan hanya $20 \%$ guru yang memberikan umpan balik(feedback) kepada siswa.

Hal tersebut dapat menyebabkan guru tidak dapat memperoleh informasi tentang kekuatan dan kelemahan belajar siswa. Sebagai akibatnya, guru belum memperoleh pedoman yang jelas dalam menindaklanjuti hasil pembelajaran. Demikian juga dengan siswa, siswa tidak mendapatkan umpan balik yang memadai tentang hasil belajarnya dan tidak memiliki acuan untuk memperbaiki proses dan hasil belajarnya [6]. Maka dari itu, diperlukan salah satu asesmen yang dapat digunakan untuk memperoleh informasi kekuatan dan kelemahan belajar siswa, mendorong dan meningkatkan pemahaman siswa. Asesmen tersebut dikenal dengan asesmen formatif.

Asesmen formatif merupakan penilaian yang dapat menggambarkan bagaimana siswa dan guru dalam melakukan pembelajaran. Asesmen formatif juga dapat dijadikan sebagai bukti belajar siswa untuk menentukan hingga tahap apa pembelajaran harus dilakukan seperti memutuskan/memberhentikan pembelajaran, melanjutkan pembelajaran dan bagaimana pembelajaran telah sampai kepada tujuan pembelajaran yang hendak dicapai. Asesmen formatif juga dapat dijadikan praktik yang dapat membantu siswa dalam meningkatkan pemahamannya [7].

Asesmen formatif juga merupakan proses yang digunakan oleh guru dan siswa selama pengajaran yang memberikan umpan balik untuk menyesuaikan pengajaran dan pembelajaran yang sedang berlangsung untuk meningkatkan pencapaian siswa dari hasil yang diharapkan secara struktural [8].

Asesmen formatif dapat menjadi strategi yang efektif dalam menanggulangi kurang optimalnya penilaian selama proses belajar mengajar. Karena karakteristik yang dimiliki oleh asesmen ini dapat mendorong terjadinya peningkatan konsep yang dialami siswa serta dapat memberikan umpan balik selama kegiatan pembelajaran berlangsung [9].

Implementasi asesmen formatif dalam pembelajaran dapat dipilah menjadi asesmen formatif yang bersifat informal dan asesmen formatif yang bersifat formal. Asesmen formatif yang bersifat formal dilakukan misalnya dengan meminta siswa untuk mengerjakan tes, kuis, mengembangkan tulisan atau karya yang lain. Asesmen informal merupakan kegiatan-kegiatan dalam pembelajaran yang dipilih oleh guru untuk menguak informasi dari siswa. Kegiatan tanya jawab di kelas, meminta siswa mengomentari pendapat guru, wawancara, rekaman pembelajaran merupakan beberapa contoh asesmen formatif yang bersifat informal [6].

Sejumlah teknik yang dapat dilakukan pada asesmen formatif salah satunya adalah Concept checks. Concept checks /Cek konsep adalah bagian dari sistem penilaian formatif di mana guru dapat mengidentifikasi tujuan pembelajaran, memberikan umpan balik siswa, dan kemudian merencanakan pengajaran berdasarkan kesalahan dan kesalahpahaman siswa [10].

Concept checks digunakan untuk memeriksa apakah siswa telah mengatasi masalah mereka dan untuk memberikan kesempatan dalam menguasai konsep serta dapat memotivasi pembelajaran mereka. Terdapat dua 
teknik yang dapat digunakan dalam rangka memeriksa konsep atau pemahaman siswa selama proses pembelajaran yaitu diantaranya Short concept-checks dan Longer assessment item. Short concept-checks atau cek konsep singkat bertujuan untuk menguji siswa menggunakan pemahamannya dalam menjawab singkat pertanyaan atau masalah yang diberikan dalam bentuk format pertanyaan dimana siswa memilih jawaban. Sedangkan Longer assessment item merupakan cek konsep yang menggabungkan beberapa aspek konseptual dan memerlukan tanggapan tertulis dengan menggunakan sistem respon kelas atau strategi diskusi antar teman [10].

Evaluasi formatif atau Concept checks pada akhir pembelajaran yang dimaksud pada penelitian ini dimaksudkan untuk mengetahui sejauh mana konsepsi siswa telah terbentuk setelah mengikuti program tertentu. Dalam hal ini, evaluasi formatif juga dipandang sebagai tes diagnostik pada akhir pembelajaran. Dengan mengetahui hasil dari evaluasi formatif, siswa dengan jelas dapat mengetahui bagian mana dari materi pelajaran yang masih dirasakan sulit [11] .

Hasil penelitian Crouch \& Mazur dalam Plybour, menyatakan bahwa terdapat bukti empiris yang menunjukkan bahwa pembelajaran fisika dengan menggunakan teknik cek konsep dengan umpan balik dapat meningkatkan pembelajaran dan pemahaman siswa selama proses pembelajaran [10]. Hasil tersebut sejalan dengan hasil penelitian yang dilakukan Bulunuz, yang mengemukakan bahwa asesmen formatif secara signifikan dapat meningkatkan pemahaman siswa pada pembelajaran fisika [3].

Dengan menerapkannya asesmen formatif pada pembelajaran fisika di SMA, sangat bermanfaat bagi guru untuk mengambil keputusan yang berkaitan dengan pembelajaran dan memberikan umpan balik kepada siswa yang dapat bermanfaat untuk mengetahui hasil belajar dan merencanakan belajar berikutnya [6]. Secara empiris, asesmen formatif pada pembelajaran fisika dapat meningkatkan hasil belajar siswa dalam ranah kognitif dan siswa pun dapat membentuk strategi belajar secara mandiri [12].

Berdasarkan pemaparan diatas, maka fokus pada penelitian ini adalah untuk mengetahui efektivitas integrasi asesmen formatif concept checks pada pembelajaran fisika dalam meningkatkan kemampuan kognitif siswa.

\section{Metode Penelitian}

Tujuan dari penelitian ini adalah untuk mengetahui efektivitas integrasi asesmen formatif pada pembelajaran fisika dalam meningkatkan kemampuan kognitif siswa. Penelitian ini menggunakan metode quasi Experimental Design dengan desain penelitian yang digunakan adalah Nonequivalent Control Group Design [13]. Sehingga, penelitian ini menggunakan dua kelompok yang tidak dipilih secara acak. Dua kelompok tersebut yaitu kelompok eksperimen dan kelompok kontrol. Pada kelompok ekseperimen, dilakukan pembelajaran fisika dengan menerapkan integrasi asesmen formatif concept checks dan pada kelas kontrol dilakukan pembelajaran fisika tanpa menerapkan integrasi asesmen formatif concept checks.

Skema penelitian kelas eksperimen yang diberikan pembelajaran dengan penerapan asesmen formatif berupa Concept checks (CC) dapat dilihat pada Tabel 1.

Tabel 1. Skema Concept Checks (CC) pada kelas eksperimen

\begin{tabular}{|c|c|c|c|c|c|c|c|}
\hline \multicolumn{8}{|c|}{ Pertemuan 1} \\
\hline $\begin{array}{c}\text { Konsep } \\
\text { A }\end{array}$ & $C C$ & $\begin{array}{c}\text { Diskusi } \\
(\text { Feedback) }\end{array}$ & $\begin{array}{c}\text { Konsep } \\
\text { B }\end{array}$ & $C C$ & $\begin{array}{c}\text { Diskusi } \\
(\text { Feedback) }\end{array}$ & $\begin{array}{c}\text { Asesmen Formatif : } \\
\text { Concept checks ( } \\
\text { Quiz) }\end{array}$ & Feedback \\
\hline
\end{tabular}

Materi yang diajarkan pada kelas eksperimen dan kelas kontrol adalah materi Momentum dan Impuls dengan sub materi momentum - impuls pada pertemuan pertama dan Hukum Kekekalan Momentum Tumbukan pada pertemuan kedua. Concept Checks yang diterapkan pada kelas eksperimen sesuai dengan Tabel 1. Sebagai contoh pada penelitian ini, konsep A yang dilakukan pada pertemuan pertama adalah pembahasan mengenai Momentum. Dalam proses pembelajarannya peneliti melakukan concept checks (CC) kepada siswa lalu didiskusikan sebagai bagian dari feedback pada forum kelas. Lalu, peneliti melakukan tes 
formatif sebagai kuis dalam bentuk soal uraian di akhir pembelajaran. Feedback dari peneliti pada kuis di akhir pembelajaran tersebut berupa nilai dan komentar terhadap jawaban tulisan siswa.

Sampel pada penelitian ini adalah siswa siswa kelas X di salah satu SMA Negeri Kota Bandung sebanyak 30 siswa pada kelas eksperimen dan 29 siswa pada kelas kontrol. Pengambilan sampel tersebut dengan menggunakan teknik Convenience sampling. Convenience sampling adalah jenis teknik sampel Nonprobability Sampling di mana target populasi memenuhi kriteria praktis tertentu seperti kesediaan untuk berpartisipasi [14]. Sehingga, pada penelitian ini pengambilan sampel tidak ditentukan oleh peneliti, melainkan berdasarkan kelompok kelas yang sudah disediakan pada sekolah tempat penelitian ini dilaksanakan dan siswa yang akan mempelajari Momentum dan Impuls.

Instrumen yang digunakan dalam penelitian ini adalah tes kemampuan kognitif dan tes formatif yang disusun berdasarkan Indikator Pencapaian Kompetensi (IPK). Tes kemampuan kognitif berbentuk pilihan ganda dengan lima pilihan sebanyak 25 soal yang diberikan sebelum dan sesudah diterapkannya asesmen formatif concept checks pada pembelajaran fisika. Instrumen ini telah diuji coba terlebih dahulu kepada 30 siswa dan lima judgment ahli yang menunjukkan bahwa instrumen telah tervalidasi dan memiliki nilai reliabilitas sebesar 0,84 dengan kategori sangat tinggi. Sedangkan tes formatif berupa soal uraian yang diberikan kepada siswa di akhir pembelajaran setiap pertemuan dengan tujuan untuk memonitor sejauh mana siswa memahami materi yang diajarkan pada proses pembelajaran.

Untuk mengetahui efektivitas integrasi asesmen formatif concept checks pada pembelajaran fisika dalam meningkatkan kemampuan kognitif dilakukan dengan membandingkan kemampuan kognitif siswa kelas eksperimen dengan kelas kontrol. Efektivitas ini diuji dengan menggunakan uji t (independent sample t test) dan effect size. uji t dengan independent sample t test digunakan untuk menguji perbedaan yang signifikan antara dua kelompok yang tidak berpasangan [13]. Sedangkan, effect size digunakan untuk mengukur seberapa efektif hubungan antara variabel bebas (yang mempengaruhi) dan variabel terikat (yang dipengaruhi) [15].

\section{Hasil Penelitian dan Pembahasan}

\section{Hasil penelitian}

Pada bagian ini dibahas mengenai hasil penelitian efektivitas asesmen formatif concept checks dalam meningkatkan kemampuan kognitif siswa yang didapatkan dari hasil rerata skor pretest dan posttest. Berikut disajikan hasil penelitian kemampuan kognitif siswa berupa statistik deskriptif, uji perbedaan dengan independent sample t test dan uji dampak/effect size.

Tabel 2. Statistik deskriptif data pretest-posttest

\begin{tabular}{cccccc}
\hline Kelas & Jumlah & \multicolumn{2}{c}{ Skor Rerata } & \multicolumn{2}{c}{ Std. Deviasi } \\
& sampel & Pretest & Posttest & Pretest & Posttest \\
\hline Eksperimen & 30 & 39,87 & 76,80 & 18,77 & 16,64 \\
Kontrol & 29 & 8,06 & 69,52 & 8,84 & 11,08 \\
\hline
\end{tabular}

Berdasarkan Tabel 2. dapat dilihat secara deskriptif bahwa kemampuan kognitif siswa pada saat pretest mendapat rerata skor 39,87 dan pada saat posttest rerata skor meningkat menjadi 76,8. Artinya terdapat peningkatan kemampuan kognitif siswa setelah diterapkannya asesmen formatif pada pembelajaran fisika.

Selanjutnya dilakukan uji hipotesis untuk mengetahui perbedaan secara signifikan pada kemampuan kognitif siswa maka dilakukan uji normalitas dan uji homogenitas terlebih dahulu dengan menggunakan software IBM SPSS 25. Pengolahan hasil uji normalitas data N-gain dapat dilihat pada Tabel 3 berikut.

Tabel 3. Hasil Uji Normalitas data N-gain kemampuan kognitif siswa

\begin{tabular}{lll}
\hline Aspek & Signifikansi & Interpretasi \\
\hline
\end{tabular}




\begin{tabular}{ccc}
\hline N-gain Eksperimen & 0,14 & Data terdistribusi \\
N-gain Kontrol & 0,06 & normal \\
\hline
\end{tabular}

Hasil uji normalitas data $\mathrm{N}$-gain berdasarkan Tabel 3 menunjukkan bahwa pada kelas eksperimen sebesar 0,14 dan untuk kelas kontrol yaitu 0,06. Pada kriteria uji 5\% nilai signifikansi tersebut lebih besar dari 0,05 (sig.> 0,05). Sehingga, data N-gain pada kelas eksperimen maupun kelas kontrol berdistribusi normal.

Tabel 4. Hasil Uji Homogenitas data N-gain kemampuan kognitif siswa

\begin{tabular}{ccc}
\hline Aspek & Signifikansi & Interpretasi \\
\hline & 0,78 & Homogen \\
\hline
\end{tabular}

Hasil uji homogenitas berdasarkan Tabel 4 diketahui bahwa data $\mathrm{N}$-gain kemampuan kognitif siswa kelas eksperimen dan kelas kontrol didapatkan signifikansi yaitu 0,78. Pada kriteria uji 5\% nilai signifikansi tersebut lebih besar dari 0,05 (sig>0,05). Sehingga, data N-gain pada kelas eksperimen maupun kelas kontrol memiliki varians yang sama atau homogen.

Hasil uji normalitas dan uji homogenitas N-gain kemampuan kognitif siswa kelas eksperimen dan kontrol berdistribusi normal dan homogen, maka untuk mengetahui perbedaan yang signifikan kemampuan kognitif siswa dilakukan uji parametrik, yaitu Independent Sample t test. Adapun rumusan hipotesis adalah sebagai berikut:

$\mathrm{H}_{0}$ : Tidak terdapat perbedaan kemampuan kognitif siswa pada pembelajaran fisika dengan yang menerapkan asesmen formatif concept checks dan yang tidak.

$\mathrm{H}_{1}$ : Terdapat perbedaan kemampuan kognitif siswa pada pembelajaran fisika dengan yang menerapkan asesmen formatif concept checks dan yang tidak

Tabel 5. Hasil Uji Independent Sample t test data N-gain

\begin{tabular}{ccc}
\hline Aspek & Sig. (2-tailed) & Keterangan \\
\hline $\mathrm{N}$-gain & 0,01 & $\mathrm{H}_{0}$ ditolak, $\mathrm{H}_{1}$ diterima \\
\hline
\end{tabular}

Berdasarkan Tabel 5 nilai Sig. (2-tailed) yang diperoleh adalah sebesar 0,01. Pada kriteria uji 5\% nilai signifikansi tersebut yang lebih kecil daripada 0,05 (sig.< 0,05). Sehingga, $\mathrm{H}_{0}$ ditolak dan $\mathrm{H}_{1}$ diterima. Maka kesimpulannya, terdapat perbedaan kemampuan kognitif siswa antara kelas yang mengintegrasikan asesmen formatif concept checks dengan kelas yang tidak mengintegrasikan asesmen formatif concept checks

Selanjutnya dilakukan uji dampak/effect size terhadap hasil posttest siswa kelas eksperimen maupun kelas kontrol untuk mengetahui seberapa besar pengaruh integrasi asesmen formatif concept checks dalam meningkatkan kemampuan kognitif siswa.

Tabel 6. Hasil Uji dampak/effect size

\begin{tabular}{cccccc}
\hline $\mathbf{M}_{\mathbf{E}}$ & $\mathbf{M}_{\mathbf{K}}$ & $\mathbf{S D}_{\mathbf{E}}$ & $\mathbf{S D}_{\mathbf{K}}$ & $\mathbf{d}$ & Keterangan \\
\hline 76,80 & 69,52 & 16,64 & 11,08 & 0,72 & Sedang \\
\hline
\end{tabular}

\section{Pembahasan}

Asesmen formatif Concept checks yang dilakukan pada penelitian ini berupa kuis pertanyaan yang sudah disesuaikan dengan indikator Pencapaian Kompetensi dan diterapkan pada pembelajaran fisika. Asesmen formatif concept checks ini bertujuan untuk melihat sejauh mana siswa dapat menangkap pengetahuannya selama proses pembelajaran berlangsung. Dengan menjawab kuis tersebut, peneliti dapat mengetahui sejauh 
mana siswa menguasai konsep apakah sudah baik ataupun sebaliknya sehingga feedback yang diberikan peneliti mampu meluruskan konsepsi siswa yang kurang. Hal tersebut bedasarkan apa yang dikemukakan oleh Black dalam Sherman, yang mengemukakan bahwa asesmen formatif merupakan salah satu alat pedagogis yang digunakan untuk meningkatkan pemahaman siswa dengan cara memperoleh informasi secara aktual dengan mengadaptasi pengajaran dan menemukan kebutuhan pembelajaran [16]. Berikut adalah salah satu jawaban siswa terhadap kuis yang diberikan peneliti sehingga siswa tersebut mendapatkan feedback berupa komentar mengenai capaian kognitif siswa.

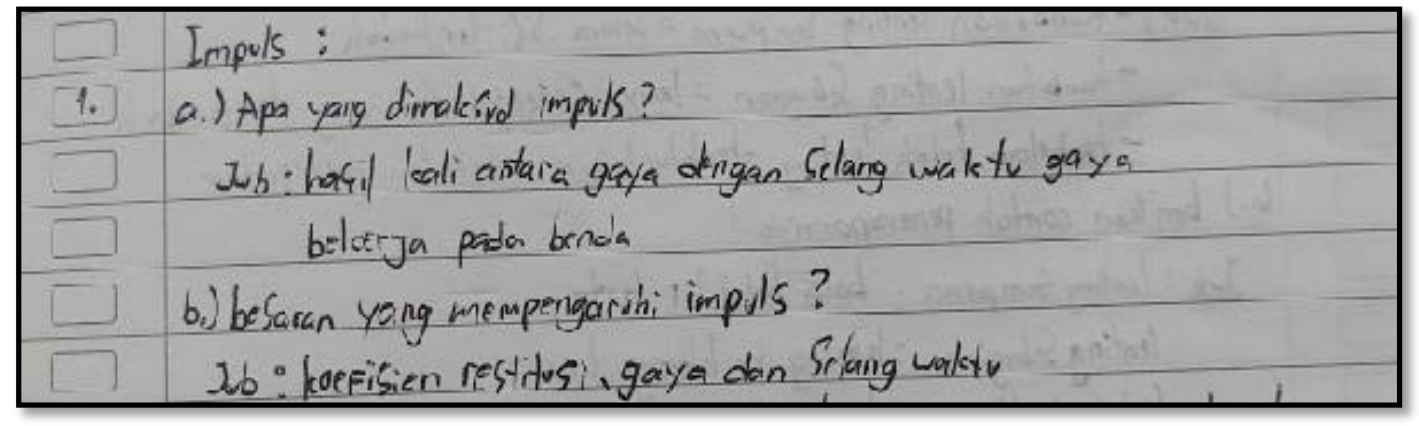

Gambar 1. Hasil jawaban kuis siswa

Salah satu contoh jawaban kuis siswa diatas menunjukkan siswa tersebut masih keliru dalam yang menjawab sebuah pertanyaan. Sehingga peneliti memberikan umpan balik/feedback berupa komentar terhadap jawaban tersebut. Feedback berupa komentar terhadap jawaban siswa yang bertujuan untuk mendorong para siswa untuk melakukan perbaikan yang dapat mempengaruhi peningkatan kemampuan kognitif.

Asesmen formatif Concept checks ini dikategorikan efektif jika hasil uji statistik menujukkan terdapat perbedaan secara signifikan antara kelas eksperimen dan kelas kontrol serta hasil effect size yang menunjukan interpretasi ukuran sedang dan/atau besar. Berdasarkan temuan pada Tabel 5 dan Tabel 6 dengan membandingkan hasil kemampuan kognitif siswa antara kelas kontrol dan kelas eksperimen didapatkan bahwa terdapat perbedaan secara signifikan (Sig. $=0,01$ ) terhadap kemampuan kognitif siswa dan perhitungan effect size $(\mathrm{d}=0,72)$ yang masuk pada kategori sedang. Sehingga, dapat dikatakan bahwa asesmen formatif concept checks pada pembelajaran fisika efektif dalam meningkatkan kemampuan kognitif siswa. Hal tersebut sesuai dengan yang dikemukakan Bulunuz yang menyatakan bahwa salah satu siklus yang dapat meningkatkan efektivitas pembelajaran yaitu dengan menerapkannya asesmen formatif ke dalam pembelajaran dan secara signifikan dapat meningkatkan pemahaman siswa pada pembelajaran fisika [3]. Dan juga menurut penelitian yang dilakukan Crouch \& Mazur dalam Plybour yang menyatakan bahwa terdapat bukti empiris yang menunjukkan bahwa pembelajaran dengan menggunakan teknik concept checks dengan umpan balik dapat meningkatkan pembelajaran dan pemahaman siswa [10].

\section{Kesimpulan}

Efektivitas integrasi asesmen formatif concept checks pada pembelajaran fisika dalam meningkatkan kemampuan kognitif siswa diperoleh dari hasil analisis menggunakan perhitungan uji t dan effect size. secara keseluruhan, integrasi asesmen formatif concept checks efektif dalam meningkatkan kemampuan kognitif siswa. Dilihat dari uji statistik yang menunjukkan bahwa integrasi asesmen formatif concept checks memiliki perbedaan yang signifikan dengan pembelajaran fisika yang tidak diterapkannya asesmen formatif concept checks dan hasil effect size pada kategori sedang yang artinya memiliki efek yang cukup tinggi terhadap peningkatan kemampuan kognitif siswa. Bagi penelitian selanjutnya, masih banyak keterbatasan dan kekurangan dalam penelitian ini, juga masih banyak kajian yang belum dilakukan, misalnya asesmen formatif dengan teknik lain pada materi fisika yang sama atau materi fisika yang lain, sehingga dapat menghasilkan penelitian yang mampu mensinergikan setiap materi fisika dalam meningkatkan kemampuan kognitif. 


\section{Kepustakaan}

[1] Kemendikbud, Panduan Penilaian oleh Pendidik dan Satuan Pendidikan Sekolah Menengah Atas. Jakarta: Direktorat Pembinaan Sekolah Menen, 2017.

[2] E. Gama and M. F. Barroso, "Student's Video Production as Formative Assessment," Sci. Educ., vol. 8, pp. 165-171, 2017, doi: 10.14712/18047106.740.

[3] N. Bulunuz, M. Bulunuz, and H. Peker, "Effects of formative assessment probes integrated in extracurricular hands-on science: Middle school students' understanding," J. Balt. Sci. Educ., vol. 13, no. 2, pp. 243-258, 2014.

[4] Sriyati, "Peran Asesmen Formatif dalam Membentuk Habits of Mind Mahasiswa,” Doctoral dissertation, Universitas Pendidikan Indonesia, 2011.

[5] E. W. N. Sofianto, W. Wartono, and S. Kusairi, "Pengaruh Balikan Formatif Terintergrasi Strategi Pembelajaran Diagram Vee Dan Kemampuan Awal Terhadap Penguasaan Konsep Siswa,” J. Pendidik. Fis. Indones., vol. 12, no. 2, pp. 183-188, 2016, doi: 10.15294/jpfi.v12i2.4269.

[6] S. Kusairi, “Analisis Asesmen Formatif Fisika Sma Berbantuan Komputer,” J. Penelit. dan Eval. Pendidik., vol. 16, no. 3, pp. 68-87, 2013, doi: 10.21831/pep.v16i0.1106.

[7] B. Kean, "Developing formative assessment strategies in the Primary Years Programme," no. 2009, pp. 1-30, 2014.

[8] R. E. Bennett, "Formative assessment: A critical review," Assess. Educ. Princ. Policy Pract., vol. 18, no. 1, pp. 5-25, 2011, doi: 10.1080/0969594X.2010.513678.

[9] Y. Yin, M. K. Tomita, and R. J. Shavelson, "Using Formal Embedded Formative Assessments Aligned with a Short-Term Learning Progression to Promote Conceptual Change and Achievement in Science," Int. J. Sci. Educ., vol. 36, no. 4, pp. 531-552, 2014, doi: 10.1080/09500693.2013.787556.

[10] C. Plybour, "Integrating formative assessment into physics instruction: The effect of formative vs. summative assessment on student physics learning and attitudes," ProQuest Diss. Theses, p. 170, 2015, [Online]. Available: https://search.proquest.com/docview/1697283982?accountid=15272.

[11] Arikunto, Dasar Dasar Evaluasi Pendidikan. Jakarta: Bumi Aksara, 2012.

[12] A. S. Ningrum, C. Ertikanto, and U. Rosidin, "Development of Formative Assessment Models bt GuidedInquiry based to Foster Self-Regulation of Student High School,” vol. 6, pp. 100-116, 2018.

[13] Sugiyono, Metode Penelitian Pendidikan (Pendekatan Kuantitatif, Kualitatif, dan R\&D). Bandung: Alfabeta, 2015 .

[14] I. Etikan, "Comparison of Convenience Sampling and Purposive Sampling,” Am. J. Theor. Appl. Stat., vol. 5, no. 1, p. 1, 2016, doi: 10.11648/j.ajtas.20160501.11.

[15] C. J. Dunst, D. W. Hamby, and C. M. Trivette, "Guidelines for Calculating Effect Sizes for Practice-Based Research Syntheses," Centerscope, vol. 3, no. 1, pp. 1-10, 2004.

[16] T. J. Sherman et al., "Effect of quiz format on student performance and answer-changing behaviour on formative assessments," J. Biol. Educ., vol. 00, no. 00, pp. 1-15, 2019, doi: 10.1080/00219266.2019.1687106. 